\title{
Electrochemiluminescence Detection of Silver Ion Based on Trigeminal Structure of DNA
}

\author{
Zhejian Li, ${ }^{* *, a}$ Xuemei Fan, ${ }^{a}$ Baoyue Cao, ${ }^{a}$ Fei Yuan, ${ }^{a}$ Fengying Chen ${ }^{a}$ and Shumin Wang*,a \\ ${ }^{a}$ College of Chemical Engineering and Modern Materials, Shangluo University, \\ 726000 Shangluo, P. R. China
}

\begin{abstract}
A novel electrochemiluminescence (ECL) biosensor for highly sensitive and selective detection of $\mathrm{Ag}^{+}$is developed based on the sensitive "turn-on" structure-switching trigeminal structure of deoxyribonucleic acid (DNA-TS). DNA-TS consists of three oligonucleotides hybridized to form three double-stranded DNA like Y-shaped DNA structure. The formation of DNA-TS makes the ECL sign $\mathrm{Ru}(\mathrm{bpy})_{2}(\mathrm{mcbpy}-\mathrm{O}-\mathrm{Su}$-ester $)\left(\mathrm{PF}_{6}\right)_{2}$ of reporter probe approach to the electrode surface and thus increase the ECL signal intensity. The "signal-on" ECL biosensor could detect $\mathrm{Ag}^{+}$concentration in the range from $1.0 \times 10^{-11}$ to $3.2 \times 10^{-9} \mathrm{~mol} \mathrm{~L}^{-1}$, and the limit of detection is $3.0 \times 10^{-12} \mathrm{~mol} \mathrm{~L}^{-1}$. The strategy is sensitive and rapid. This approach could be extended to the design of sensors for other desired heavy metal ions as well. Such ECL sensors are promising for sensitive detection of other heavy metal ions.
\end{abstract}

Keywords: electrochemiluminescence, sensor, silver-specific oligonucleotide, silver ion

\section{Introduction}

As one of the trace elements in the human body, silver ions $\left(\mathrm{Ag}^{+}\right)$are harmless in trace amounts. However, overuse of silver ion-containing compounds risks polluting the environment. ${ }^{1}$ Excess silver ions could cause inactivation of thiol-containing enzymes through the $\mathrm{Ag}-\mathrm{S}$ bond. Meanwhile, silver ions can also interact with amino acids, imidazole and carboxyl groups of various metabolites, thereby posing a threat to human health., ${ }^{2,3}$ As such, there has been increased interest in developing fast and convenient methods to detect $\mathrm{Ag}^{+}$in real-time. Traditional $\mathrm{Ag}^{+}$detection methods include plasma atomic emission spectrometry, ${ }^{4}$ atomic absorption spectrometry (AAS), ${ }^{5}$ fluorescence spectroscopy, ${ }^{6}$ ion selective electrodes (ISE), ${ }^{7}$ anodic stripping voltammetry, ${ }^{8}$ microprobes, ${ }^{9}$ etc. These conventional methods typically have poor selectivity or sensitivity, and require complicated pre-treatment of samples, as well as not being appropriate for point-of-use applications. ${ }^{10,11}$ Therefore, the development of simple methods for highly selective and sensitive determination of $\mathrm{Ag}^{+}$in life sciences, environmental protection and other related research fields is still a great challenge.

The highly selective and unique strong $\mathrm{C}-\mathrm{Ag}^{+}-\mathrm{C}$ interaction has made oligonucleotides a novel candidate for the detection of $\mathrm{Ag}^{+}$. For example, $\mathrm{Ag}^{+}$can mediate

*e-mail: zhejian2621@ 163.com; 422686504@qq.com the interaction between two cytosine molecules to form stable $\mathrm{C}-\mathrm{Ag}^{+}-\mathrm{C}$ base pairs. ${ }^{12-15} \mathrm{~A}$ series of $\mathrm{Ag}^{+}$ biosensors of very high selectivity have been developed on the basis of the interaction between $\mathrm{Ag}^{+}$and specific deoxyribonucleic acid (DNA) scaffold. ${ }^{16-19}$ These methods are based on the mismatched structure of $\mathrm{C}-\mathrm{Ag}^{+}-\mathrm{C}$, and include fluorescence analysis, ${ }^{20-22}$ colorimetric analysis, ${ }^{23}$ electrochemical detection ${ }^{24-26}$ and optical quantification. ${ }^{27}$ Electrochemiluminescence (electrogenerated chemiluminescence, abbreviated as ECL) is a combination of electrochemical and luminescence techniques. ${ }^{28,29}$ It has been proven to be a powerful analytical technique and used for the detection of compounds through coupling with molecular recognition materials, such as aptamers, DNA and antibodies. ${ }^{30,31}$

Inspired by previous researches reported in literature, ${ }^{32-34}$ the present study utilized the trigeminal structure of DNA and $\mathrm{C}-\mathrm{Ag}^{+}-\mathrm{C}$ base-pair formation to develop an ECL biosensor for $\mathrm{Ag}^{+}$detection. The mechanism of the biosensor is shown in Figure 1. First, the pretreated $\mathrm{Au}$ electrode was modified with thiolated capture probe P1, and P1 self-assembled onto the Au electrode surface via $\mathrm{Au}-\mathrm{S}$ affinity. Then 6-mercaptohexanol (MCH) was used to block the non-specific sites not occupied by P1. Lastly, a mixed solution of $\mathrm{Ru}(\mathrm{bpy})_{2}$ (mcbpy-O-Su-ester) $\left(\mathrm{PF}_{6}\right)_{2}(\mathrm{Ru} 1)$ labeled probe $\mathrm{P} 2$, auxiliary probe $\mathrm{P} 3$, and $\mathrm{Ag}^{+}$was deposited onto the modified electrode, where the mismatched pairing of $\mathrm{C}-\mathrm{Ag}^{+}-\mathrm{C}$, induced by $\mathrm{Ag}^{+}$, caused the DNA chains of $\mathrm{P} 1$, 
$\mathrm{P} 2$ and $\mathrm{P} 3$ to form a trigeminal structure of DNA, which makes the ECL sign Ru1 of reporter probe approach to the electrode surface and thus increase the ECL signal intensity. This method for the detection of $\mathrm{Ag}^{+}$is precise, sensitive, fast, easy and high selective. To the best of our knowledge we, for the first time, report the ECL detection of $\mathrm{Ag}^{+}$using the highly selective cytosine- $\mathrm{Ag}^{+}-$cytosine coordination and the sensitive "signal-on" trigeminal structure of DNA.

(a)

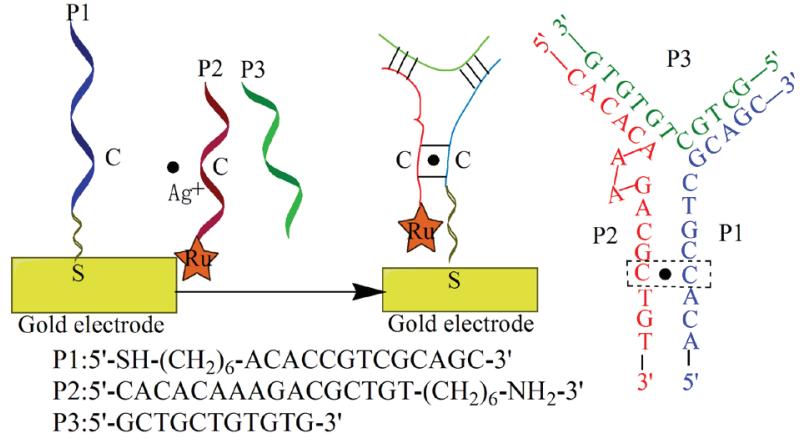

Figure 1. Schematic representation of (a) the designed electrogenerated chemiluminescence biosensor for $\mathrm{Ag}^{+}$and (b) the single $\mathrm{C}-\mathrm{Ag}^{+}-\mathrm{C}$ coordination induced synergy-dependent trigeminal DNA structure.

\section{Experimental}

\section{Reagents and instruments}

6-Mercapto-1-hexanol (MCH) and Ru(bpy $)_{2}$ (mcbpy$\mathrm{O}-\mathrm{Su}$-ester) $\left(\mathrm{PF}_{6}\right)_{2}$ (abbreviated as $\mathrm{Ru} 1$ ) were obtained from Sigma-Aldrich (USA). Oligonucleotides were synthesized and purified with polyacrylamide gel electrophoresis (PAGE) by Shanghai Sangon Biological Engineering Technology \& Services Co., Ltd. (China). Their sequences are listed as: capture probe (5'-SH- $\left(\mathrm{CH}_{2}\right)_{6}$-ACACCGTCGCAGC-3'), reporter probe (5'-CACACAAAGACGCTGT- $\left(\mathrm{CH}_{2}\right)_{6}-\mathrm{NH}_{2}-3$ ') and auxiliary probe (5'-GCTGCTGTGTG-3').

$N, N$-Dimethylformamide (DMF), anhydrous ethanol and tri- $n$-propylamine (TPrA) were purchased from the Xi'an Chemical Reagent Factory (China). All other reagents (analytical grades) were purchased from Sinopharm Chemical Reagent Co., Ltd. (China). Water used in this study was double deionized ultrapure water (Milli-Q 18.2 M $\Omega \mathrm{cm})$. DNA buffer $\left(0.1 \mathrm{~mol} \mathrm{~L}^{-1} \mathrm{NaCl}\right.$ in $10 \mathrm{mmol} \mathrm{L}^{-1}$ Tris-HCl, $\mathrm{pH}$ 7.4) was used to dissolve and preserve DNA.

The device for ECL measurement consisted of a CHI600B Workstation (Shanghai CH Instruments, Inc., China) and an Ultra-Sensitive Luminescence Analyzer (Institute of Biophysics, Chinese Academy of Sciences,
China) with a traditional three-electrode system. The three-electrode system consisted of a fabricated sensor or a gold electrode (diameter $(\phi)=2.0 \mathrm{~mm}$ ) with modifications as the experimental electrode, a platinum wire as the counter electrode, and an $\mathrm{Ag} / \mathrm{AgCl}$ electrode (in saturated $\mathrm{KCl}$ solution) as the reference electrode. The UV-Vis spectrum in this study was obtained on a UV-2450 UV-Vis spectrometer (Shimadzu Co., Japan). Fluorescence images were obtained with an Olympus IX-51 inverted microscope (Olympus Corporation, Japan) that was equipped with a mercury lamp (Olympus, Japan) and Olympus Dual CCD DP80 camera.

\section{Synthesis of reporter probe}

Briefly, $200 \mu \mathrm{L}$ (2 OD (optical density), about $66 \mu \mathrm{g}$ ) of $3^{\prime} \mathrm{NH}_{2}$-oligonucleotides was added into $200 \mu \mathrm{L}$ of Ru1 $\left(1.0 \times 10^{-3} \mathrm{~mol} \mathrm{~L}^{-1}\right.$, dissolved in DMF $)$ and incubated with agitation at room temperature for $12 \mathrm{~h}$. The above mixture was then added to $3.0 \mathrm{~mL}$ of anhydrous ethanol and $100 \mu \mathrm{L}$ solution of sodium acetate $(3 \mathrm{~mol} \mathrm{~L}-1)$ and then cooled at $-16{ }^{\circ} \mathrm{C}$ for $24 \mathrm{~h}$. The solution was then centrifuged at $12000 \mathrm{rpm} \mathrm{min}^{-1}$ for $30 \mathrm{~min}$ with refrigeration. The precipitate was washed with $2 \mathrm{~mL}$ of cold ethanol several times to remove unbound Ru1. The Ru1-labeled oligonucleotide probes were dissolved in $1.0 \mathrm{~mL}$ of $0.10 \mathrm{~mol} \mathrm{~L}^{-1}$ phosphate-buffered saline (PBS), and stored at $-16{ }^{\circ} \mathrm{C}$ until usage.

\section{Preparation of ECL biosensor}

Prior to each measurement, the Au electrodes were first cleaned by immersing them in piranha solution ( $30 \% \mathrm{H}_{2} \mathrm{O}_{2}$ :concentrated $\mathrm{H}_{2} \mathrm{SO}_{4}, 1: 3 \mathrm{v} / \mathrm{v}$ ) for $2 \mathrm{~h}$ and then rinsed with Milli-Q water. Subsequently, the Au electrodes were polished with $0.03 \mu \mathrm{m} \mathrm{Al} \mathrm{O}_{3}$ slurry, followed by sonication with Milli-Q water, ethanol and Milli-Q water for $3 \mathrm{~min}$ in each, to rinse off any residual $\mathrm{Al}_{2} \mathrm{O}_{3}$ powder. The Au-electrode was then electrochemically cleaned in a $0.1 \mathrm{~mol} \mathrm{~L}^{-1} \mathrm{H}_{2} \mathrm{SO}_{4}$ solution by potential scanning within the potential range of -0.2 to $1.5 \mathrm{~V}$ until a reproducible voltammogram of gold was obtained. The electrode was then washed with water then blown dry with nitrogen.

Next, $6 \mu \mathrm{L}$ of solution containing $0.5 \mu \mathrm{mol} \mathrm{L} \mathrm{L}^{-1}$ capture probe was dropped onto the pretreated Au electrode and incubated for $4 \mathrm{~h}$. The probe was washed twice with $0.1 \mathrm{~mol} \mathrm{~L}^{-1} \mathrm{PBS}$ solution to remove unbound capture probe. To reduce non-specific adsorption, the modified electrode was incubated in $1 \mu \mathrm{mol} \mathrm{L}^{-1} 6$-mercaptoethanol for $1 \mathrm{~h}$ so the capture probe could form a single-direction monolayer on the surface of the electrode. 


\section{ECL measurements}

$6.0 \mu \mathrm{L}$ of mixture solution containing $1.0 \mu \mathrm{mol} \mathrm{\textrm {L } ^ { - 1 }}$ of reporter probe, $1 \mu \mathrm{mol} \mathrm{L^{-1 }}$ of auxiliary probe and different concentrations of $\mathrm{Ag}^{+}$, was dropped onto the biosensor and incubated for $35 \mathrm{~min}$, followed by 3 washes with the washing buffer. The biosensor treated with $\mathrm{Ag}^{+}$was then used as the working electrode in the ECL cell containing $3.0 \mathrm{~mL}$ of $0.10 \mathrm{~mol} \mathrm{~L}^{-1}$ TPrA-10 mmol L-1 PBS (pH 7.4) solution. The ECL measurement was performed with a scanning rate of $50 \mathrm{mV} \mathrm{s}^{-1}$ and a range of 0-1.4 V. The $\mathrm{Ag}^{+}$concentrations were quantified based on the ECL peak intensity change, $\Delta \mathrm{I}=\mathrm{I}-\mathrm{I}_{0}$, where $\mathrm{I}_{0}$ and $\mathrm{I}$ were ECL peak intensity before and after the ECL biosensing system interacts with $\mathrm{Ag}^{+}$, respectively. ECL detection and electrochemical impedance spectroscopy (EIS) measurements were both conducted in saturated and still air at ambient temperature.

\section{Results and Discussion}

\section{Characteristics of the reporter probe}

The reporter probe was characterized by UV-Vis absorption spectrophotometry and the fluorescence imaging. Figure 2A shows the UV-Vis spectrum of probe DNA (P2), Ru1 and reporter probe (P2-Ru1). A characteristic DNA peak was observed at $260 \mathrm{~nm}$ for the probe DNA in Figure 2a. Three characteristic peaks were observed between 220 and $500 \mathrm{~nm}$ for Ru1 in Figure 2b. The UV-Vis spectrum of the reporter probe was shown in Figure 2c, where the characteristic peaks at 278 and $258 \mathrm{~nm}$ corresponded to the absorption of Ru1 at 287 and $260 \mathrm{~nm}$, respectively, with slight shift towards blue light. The absorption of the reporter probe at $460 \mathrm{~nm}$ was characteristic of absorption of the metallic ruthenium, which indicates conjugation of Ru1 into the DNA P2.

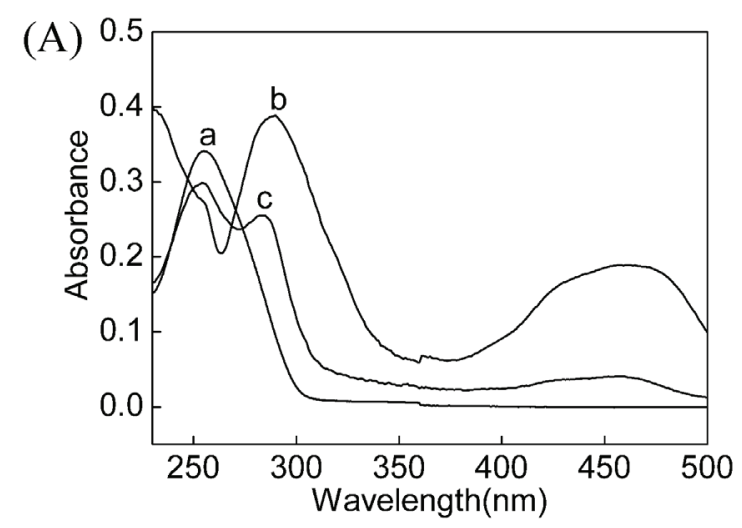

The reporter probe concentration was calculated to be $1.3 \times 10^{-6} \mathrm{~mol} \mathrm{~L}^{-1}$ on the basis of the UV-Vis spectra. Figure $2 \mathrm{~B}$ shows the fluorescence imaging of the reporter probe. These manifested that the ECL signal substance Ru1 had been coupled with the DNA P2.

\section{Characteristics of the electrode assembling process}

EIS was verified to be a powerful technique to determine the fabrication of the sensing interface and binding process. ${ }^{35}$ To investigate the surface interactions, EIS measurements were tested. Figure 3 displays the impedance spectra in the form of a Nyquist plot obtained at the different electrodes. The fabrication of the sensing interface and binding process were subjected to the step-by-step modification process. The electron transfer resistance (Ret) at the bare Au electrode was about $145.91 \Omega$ (Figure 3, curve a). This is attributed to that the bare gold electrode is an ideal conductor. After thiolated P1 self-assembled on the Au electrode surface, the Ret value increased to $1659.6 \Omega$ (Figure 3 , curve b), which indicated successful fixation of the $\mathrm{P} 1$ chain onto the $\mathrm{Au}$ electrode. After blocking with $1 \mathrm{mmol} \mathrm{L}^{-1} \mathrm{MCH}$, the Ret value increased to $4513.7 \Omega$ (Figure 3 , curve c), which is caused by the blocking of the residual sites on the electrode surface by the thiol bonds in $\mathrm{MCH}$, and further reduction of the transmission of $\left[\mathrm{Fe}(\mathrm{CN})_{6}\right]^{3-14-}$ on the electrode surface. After further reaction with $6 \mu \mathrm{L}$ mixture solution including $1.0 \mu \mathrm{mol} \mathrm{L}-1 \mathrm{P} 2 / \mathrm{P} 3$ and $1 \mathrm{nmol} \mathrm{L}{ }^{-1} \mathrm{Ag}^{+}$ for $60 \mathrm{~min}$, the Ret of the biosensor increased further, with the Ret value increasing from 4513.7 to $10206 \Omega$ (Figure 3, curve d). This is mainly due to the negative charge of DNA phosphate backbone, which can repel negative charged $\left[\mathrm{Fe}(\mathrm{CN})_{6}\right]^{3-14-}$, preventing $\left[\mathrm{Fe}(\mathrm{CN})_{6}\right]^{3-14-}$ from reaching the electrode surface and therefore increasing the electrode impedance. All the above results indicated successful preparation of the ECL biosensor.

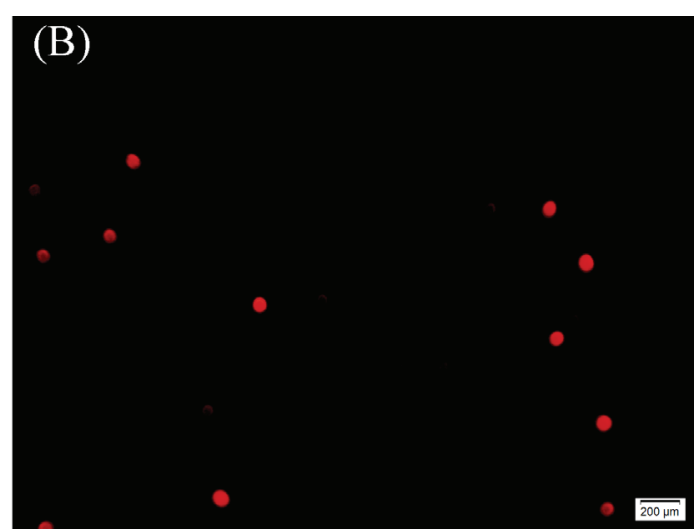

Figure 2. (A) UV-Vis absorption spectra and (B) fluorescence CCD imaging of the reporter probe. (a) $10.0 \mu \mathrm{mol} \mathrm{L} \mathrm{L}^{-1} \mathrm{P} 2$; (b) $9.0 \mu \mathrm{mol} \mathrm{L} \mathrm{L}^{-1} \mathrm{Ru} 1$ and (c) $1.3 \mu \mathrm{mol} \mathrm{L} \mathrm{L}^{-1}$ reporter probe. 


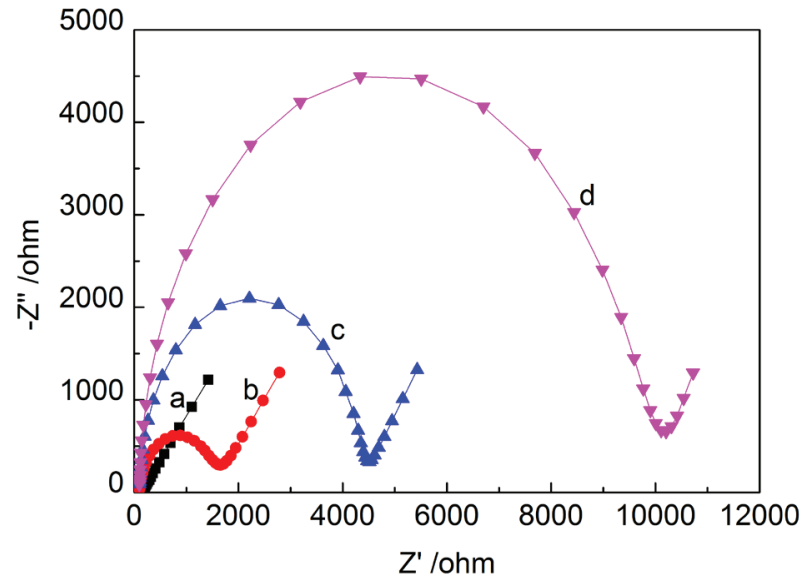

Figure 3. Nyquist diagram for the Faradaic impedance obtained at different electrodes in $5.0 \mathrm{mmol} \mathrm{L}^{-1}\left[\mathrm{Fe}(\mathrm{CN})_{6}\right]^{3-14}$ solution (containing $10 \mathrm{mmol} \mathrm{L}^{-1} \mathrm{KCl}$ ) with a scanning rate of $50 \mathrm{mV} \mathrm{s}^{-1}$ in the frequency range from $100 \mathrm{kHz}$ to $0.1 \mathrm{~Hz}$. (a) Bare gold electrode; (b) P1/gold electrode; (c) $\mathrm{P} 1 / \mathrm{MCH} /$ gold electrode; (d) $\mathrm{P} 3 / \mathrm{P} 2 / \mathrm{P} 1 / \mathrm{MCH} /$ gold electrode after interaction with $1 \mathrm{nmol} \mathrm{L}^{-1} \mathrm{Ag}^{+}$.

\section{Feasibility of detecting $\mathrm{Ag}^{+}$through $\mathrm{ECL}$ measurement}

Figure 4 shows the ECL intensity changes before and after the ECL biosensor reacted with $3.2 \times 10^{-10}$ or $3.2 \times 10^{-9} \mathrm{~mol} \mathrm{~L}^{-1} \mathrm{Ag}^{+}$solution, respectively. The ECL peak values after the sensor reacted with $\mathrm{Ag}^{+}$of $3.2 \times 10^{-10}$ and $3.2 \times 10^{-9} \mathrm{~mol} \mathrm{~L}^{-1}$ were 7605 (Figure 4, curve b) and 14011 (Figure 4, curve c), respectively, indicating that detection of $\mathrm{Ag}^{+}$with the developed ECL sensor was feasible.

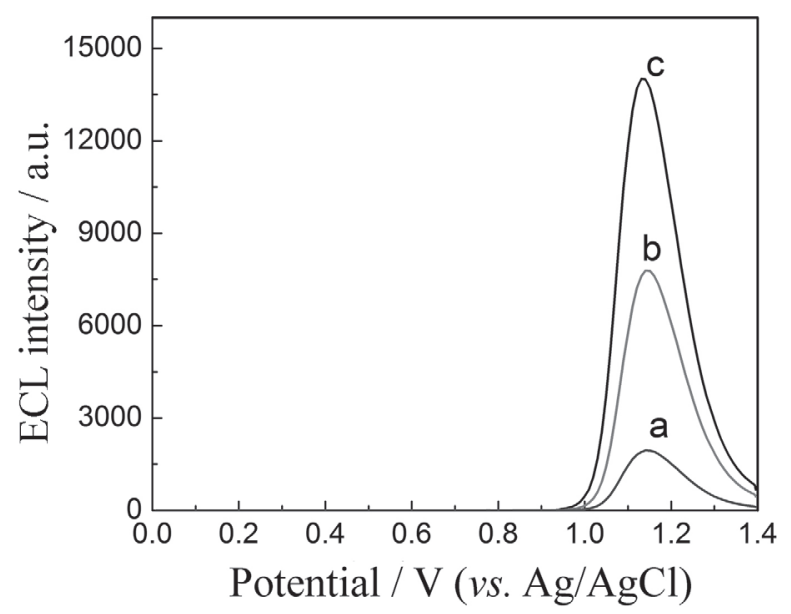

Figure 4. ECL intensity-potential profiles of the ECL biosensors before (line a) and after interaction with $3.2 \times 10^{-10} \mathrm{~mol} \mathrm{~L}^{-1}$ (line b) and $3.2 \times 10^{-9} \mathrm{~mol} \mathrm{~L}^{-1} \mathrm{Ag}^{+}$(line c). The ECL measurement was performed in the ECL cell containing $3.0 \mathrm{~mL}$ of $0.10 \mathrm{~mol} \mathrm{~L}^{-1} \mathrm{TPrA}-10 \mathrm{mmol} \mathrm{L}^{-1} \mathrm{PBS}$ $(\mathrm{pH} 7.4)$ solution with a scanning rate of $50 \mathrm{mV} \mathrm{s}^{-1}$ and a range of $0-1.4 \mathrm{~V}$.

\section{Optimization of experimental conditions}

Optimization of the auxiliary probe concentration is shown in Figure 5a. The concentration of the target $\mathrm{Ag}^{+}$ solution was $1.0 \times 10^{-9} \mathrm{~mol} \mathrm{~L}^{-1}$, with a fixed mixture probe hybridization time of $40 \mathrm{~min}$. DNA probes $\mathrm{P} 2$ and $\mathrm{P} 3$ were mixed at the same concentration and the concentration of auxiliary probes was changed in the range from 0 to $1.0 \mu \mathrm{mol} \mathrm{L}^{-1}$ simultaneously, to investigate the effect of the concentration of auxiliary probe on ECL intensity. It should be noted that the concentration of the auxiliary probe had been maintained at the same level and were much higher than DNA P1 concentration. In Figure 5a, ECL intensity increased rapidly as the concentration of auxiliary probes increased within the range of 0 to $1.0 \mu \mathrm{mol} \mathrm{L}^{-1}$. The increasing rate slowed down after the auxiliary probes reached $0.6 \mu \mathrm{mol} \mathrm{L} \mathrm{L}^{-1}$. The ECL intensity hardly increased with increasing concentration of auxiliary probes after the concentration passed $1.0 \mu \mathrm{mol} \mathrm{L} \mathrm{L}^{-1}$. The auxiliary probe concentration of $1.0 \mu \mathrm{mol} \mathrm{L}^{-1}$ was therefore selected for all the following experiments in consideration of improving the sensitivity and saving reagent.

The relationship between the incubation duration of the biosensor with DNA probes $\mathrm{P} 2, \mathrm{P} 3$ and $\mathrm{Ag}^{+}$solution and the ECL intensity is shown in Figure 5b. When the incubation duration increased from 5 to $10 \mathrm{~min}$, the ECL signal increased from 1200 to 4500 . When the incubation duration increased from 10 to $30 \mathrm{~min}$, the ECL intensity kept increasing, plateauing at 9500 at the end. An
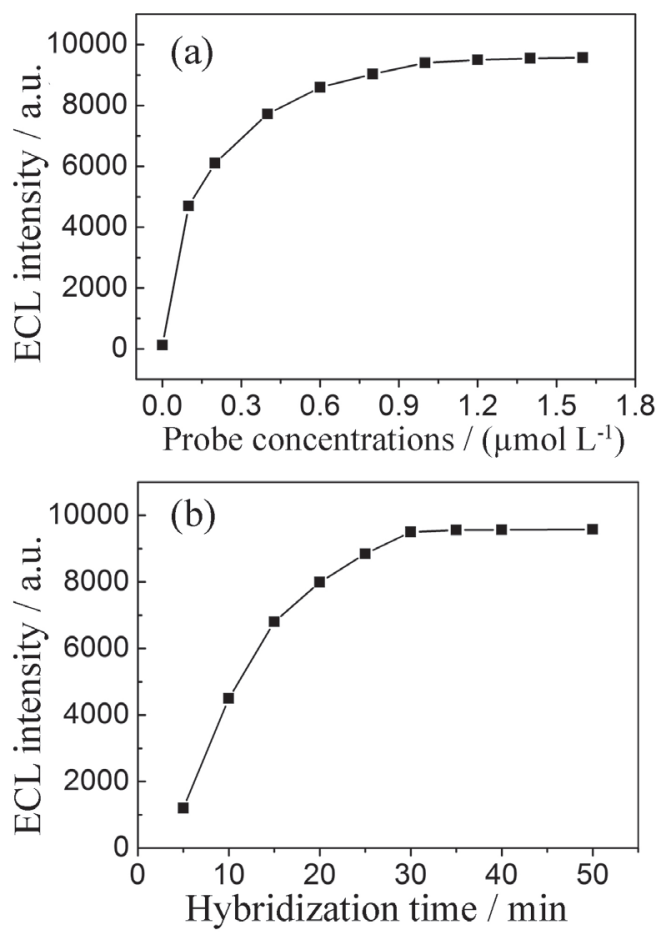

Figure 5. Effects of the concentration of auxiliary probes and binding time on the ECL intensity. (a) Dependence of the ECL intensity of the biosensor on the concentration of auxiliary probes; (b) dependence of the ECL intensity of biosensors on incubation time interaction with $1.0 \mathrm{nmol} \mathrm{L}{ }^{-1} \mathrm{Ag}^{+}$. The ECL measurement conditions were the same as in Figure 4. 
incubation duration of $35 \mathrm{~min}$ was selected to ensure the reaction reached completion prior to measurement.

\section{Performance of the biosensor for $\mathrm{Ag}^{+}$}

Under the optimized conditions, the ECL signal intensity at different concentrations of $\mathrm{Ag}^{+}$was determined. The response curve of ECL intensity and $\mathrm{Ag}^{+}$ concentrations is plotted in Figure 6. The peak height of the ECL signal increased in the presence of increasing $\mathrm{Ag}^{+}$concentration, and the increased ECL peak intensity was directly linearly proportional to the logarithm of the $\mathrm{Ag}^{+}$concentration within the range from $1.0 \times 10^{-11}$ to $3.2 \times 10^{-9} \mathrm{~mol} \mathrm{~L}^{-1}$. The linear regression equation was $\Delta \mathrm{I}=3869.5 \log \mathrm{C}\left(\mathrm{mol} \mathrm{L}^{-1}\right)+44309.8$, with a regression coefficient $(\mathrm{R})$ of 0.9985 . The limit of detection was $3.0 \times 10^{-12} \mathrm{~mol} \mathrm{~L}^{-1} \mathrm{Ag}^{+}$(defined as signal-to-noise $(\mathrm{S} / \mathrm{N})=3$ ), which was lower than those of the previous methods for $\mathrm{Ag}^{+}$ detection (Table 1). The low detection limit was attributed to the formation of trigeminal structure of DNA induced by a single $\mathrm{C}-\mathrm{Ag}^{+}-\mathrm{C}$ base pair, which functions as a fixer to immobilize the Ru1 onto the electrode surface, increasing the chance of the Ru1 to collide with the electrode surface and facilitating the electron transfer.

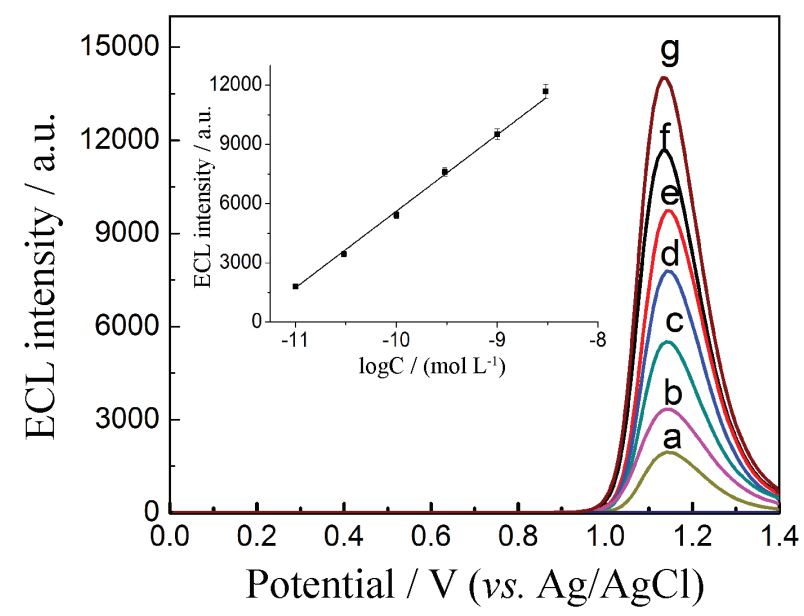

Figure 6. ECL intensity-potential profiles of the biosensor after interaction with various concentrations of $\mathrm{Ag}^{+}$under the optimized conditions. (a) 0 ; (b) $10^{-11}$; (c) $3.2 \times 10^{-11}$; (d) $10^{-10}$; (e) $3.2 \times 10^{-10}$; (f) $10^{-9}$; (g) $3.2 \times 10^{-9} \mathrm{~mol} \mathrm{~L}^{-1}$. Insert: calibration curve of $\mathrm{Ag}^{+}$. The error bars represent the standard deviation of three repetitive measurements. The ECL measurement conditions were the same as in Figure 4.

The stability of sensor was also investigated. The sensor was stored at $4{ }^{\circ} \mathrm{C}$ for 20 and 30 days, respectively, and was used to measure $1.0 \mathrm{nmol} \mathrm{L}^{-1} \mathrm{Ag}^{+}$after each storage period. The ECL signal recoveries were 95.7 and $91.8 \%$, respectively, indicating that the sensor developed in this study was stable over time under proper storage conditions.
Table 1. Comparison between previous studies and our proposed strategy

\begin{tabular}{llcc}
\hline Method & Linear range / $\left(\mathrm{mol} \mathrm{L}^{-1}\right)$ & $\begin{array}{c}\text { Limit of } \\
\text { detection / } \\
(\mathrm{mol} \mathrm{L})^{-1}\end{array}$ & Reference \\
\hline EIS & $0.1 \times 10^{-9}$ to $100 \times 10^{-6}$ & $0.05 \times 10^{-9}$ & 24 \\
EIS & $10 \times 10^{-12}$ to $100 \times 10^{-9}$ & $10 \times 10^{-12}$ & 36 \\
SWV & $2 \times 10^{-9}$ to $100 \times 10^{-9}$ & $1.5 \times 10^{-9}$ & 37 \\
SWV & $0.5 \times 10^{-9}$ to $1 \times 10^{-3}$ & $20 \times 10^{-12}$ & 26 \\
DPV & $10 \times 10^{-9}$ to $500 \times 10^{-9}$ & $1.3 \times 10^{-9}$ & 38 \\
DPV & $1 \times 10^{-12}$ to $100 \times 10^{-9}$ & $30 \times 10^{-12}$ & 39 \\
Fluorescence & $1 \times 10^{-9}$ to $100 \times 10^{-9}$ & $1 \times 10^{-9}$ & 20 \\
Fluorescence & $20 \times 10^{-9}$ to $150 \times 10^{-9}$ & $5.0 \times 10^{-9}$ & 21 \\
SPR & $50 \times 10^{-9}$ to $2 \times 10^{-6}$ & $10 \times 10^{-9}$ & 40 \\
ECL & $10 \times 10^{-12}$ to $3.2 \times 10^{-9}$ & $3.0 \times 10^{-12}$ & this work \\
\hline
\end{tabular}

EIS: electrochemical impedance spectroscopy; SWV: square wave voltammetry; DPV: differential pulse voltammetry; SPR: surface plasmon resonance; ECL: electrochemiluminescence.

The selectivity of the biosensor was investigated by hybridization with $1.0 \mathrm{nmol} \mathrm{L}{ }^{-1}$ of $\mathrm{Ag}^{+}$and $1 \mu \mathrm{mol} \mathrm{L} \mathrm{L}^{-1}$ of $\mathrm{Cu}^{2+}, \mathrm{Zn}^{2+}, \mathrm{Cd}^{2+}, \mathrm{Pb}^{2+}, \mathrm{Fe}^{2+}, \mathrm{Co}^{2+}, \mathrm{Ca}^{2+}$ and $\mathrm{Ba}^{2+}$, respectively. It was shown that the biosensor showed a remarkable response to $1.0 \mathrm{nmol} \mathrm{L}^{-1} \mathrm{Ag}^{+}$, and the $\Delta \mathrm{I}$ value in the presence of $1.0 \mu \mathrm{mol} \mathrm{L}{ }^{-1} \mathrm{Cu}^{2+}, \mathrm{Ca}^{2+}, \mathrm{Pb}^{2+}, \mathrm{Ba}^{2+}, \mathrm{Fe}^{2+}$, $\mathrm{Co}^{2+}, \mathrm{Cd}^{2+}, \mathrm{Zn}^{2+}$ and $\mathrm{Cd}^{2+}$ was similar to the background signal. The specific assembly of $\mathrm{C}-\mathrm{Ag}^{+}-\mathrm{C}$ coordination led to high selectivity for the detection of $\mathrm{Ag}^{+}$. The result shows that the approach exhibits high selectivity for $\mathrm{Ag}^{+}$, which gives it potential for future use.

The application of the ECL sensor was investigated by measuring the recovery of spiked $\mathrm{Ag}^{+}$in real water samples collected from Nanqin River from Shangluo, China. Then the water samples were filtered with $0.2 \mu \mathrm{m}$ filter membrane to remove the floating matter in the water. The $\mathrm{Ag}^{+}$concentration in the river was estimated by the proposed ECL sensor using the standard addition method. The results (Table 2) showed that the sensor constructed can be used for the detection of $\mathrm{Ag}^{+}$in real water samples.

Table 2. Detection of $\mathrm{Ag}^{+}$in water sample $(\mathrm{n}=3)$

\begin{tabular}{lcccc}
\hline Sample & $\begin{array}{c}\text { Found / } \\
\left(10^{-10} \mathrm{~mol} \mathrm{~L}^{-1}\right)\end{array}$ & $\begin{array}{c}\text { Added / } \\
\left(10^{-10} \mathrm{~mol} \mathrm{~L}^{-1}\right)\end{array}$ & $\begin{array}{c}\text { Total / } \\
\left(10^{-10} \mathrm{~mol} \mathrm{~L}^{-1}\right)\end{array}$ & $\begin{array}{c}\text { Recovery / } \\
\%\end{array}$ \\
\hline 1 & 4.60 & 5.00 & 9.69 & 102 \\
2 & 3.42 & 5.00 & 8.58 & 103 \\
3 & 4.24 & 5.00 & 9.48 & 105 \\
\hline
\end{tabular}

To investigate the regeneration of sensors, they were immersed in $100 \mathrm{nmol} \mathrm{L}^{-1} \mathrm{Na}_{2} \mathrm{~S}$ solution for $15 \mathrm{~min}$ after 
each usage. However, the ECL signal could not return to the baseline, which demonstrated that the regeneration ability of the ECL sensor proposed is not satisfactory. This is attributed to the fact that the process of applied potential broke $\mathrm{Au}-\mathrm{S}$ bond between thiol of the capture probe and the gold surface. Covalent coupling method for the fabrication of the carbon electrode-based sensor could improve regeneration ability of a biosensor. ${ }^{41}$

\section{Conclusions}

In conclusion, a novel ECL biosensor for the detection of $\mathrm{Ag}^{+}$in aqueous media has been designed. The proposed analysis system was developed for "one-step" detection of $\mathrm{Ag}^{+}$. The assay is based on the highly selective $\mathrm{C}-\mathrm{Ag}^{+}-\mathrm{C}$ coordination and the sensitive "turn-on" structure-switching trigeminal structure of DNA (DNA-TS). The DNA-TS functioned as a fixer to immobilize signal ruthenium complex of the reporter probe to collide with the electrode for fast electron transfer and increase the ECL intensity. The biosensors with a DNA-TS have exhibited improved sensitivity. The proposed biosensor showed potential application in other ECL or electrochemical biosensors, and possibly be utilized in other analytical instruments to quantitatively detect other heavy metal ions, proteins and small biomolecules.

\section{Acknowledgments}

This project was supported by the National Natural Science Foundation of China (No. 21703134) and the Natural Science Basic Research Plan in Shaanxi Province of China (No. 2018JM2040; 2018JQ2039; 18JS034).

\section{References}

1. Navarro, E.; Piccapietra, F.; Wagner, B.; Marconi, F.; Kaegi, R.; Odzak, N.; Environ. Sci. Technol. 2008, 42, 8959.

2. Dean, W. B.; Chemosphere 2000, 40, 1335.

3. Wood, C. M.; Donald, M. D. M.; Walker, P.; Grosell, M.; Barimo, J. F.; Playle, R. C.; Walsh, P. J.; Aquat. Toxicol. 2004, $70,137$.

4. Singh, R. P.; Pambid, E. P.; Analyst 1990, 115, 301.

5. Ghaedi, M.; Shokrollahi, A.; Niknam, K.; Niknam, E.; Najibi, A.; Soylak, M.; J. Hazard. Mater. 2009, 168, 1022.

6. Li, T.; Shi, L. L.; Wang, E. K.; Dong, S. J.; Chem. - Eur. J. 2009, $15,3347$.

7. Veerakumar, P.; Veeramani, V.; Chen, S.; Madhu, R.; Liu, S.; ACS Appl. Mater. Interfaces 2016, 8, 1319.

8. Baldo, M. A.; Daniele, S.; Ciani, I.; Bragato, C.; Wang, J.; Electroanalysis 2004, 16, 360.
9. Arai, Y.; Lanzirotti, A.; Sutton, S.; Davis, J.; Sparks, D.; Environ. Sci. Technol. 2003, 37, 4083.

10. Lin, Y. H.; Tseng, W. L.; Anal. Chem. 2010, 82, 9194.

11. Wang, R.; Wang, W.; Ren, H.; Chae, J.; Biosens. Bioelectron. 2014, 57, 179.

12. Zhao, C.; Qu, K. G.; Song, Y. J.; Xu, C.; Ren, J. S.; Qu, X. G.; Chem. - Eur. J. 2010, 16, 8147.

13. Hung, H. C.; Cheng, C. W.; Wang, Y. Y.; Chen, Y. J.; Chung, W. S.; Eur. J. Org. Chem. 2009, 36, 6360.

14. Zheng, H.; Yan, M.; Fan, X. X.; Sun, D.; Yang, S. Y.; Yang, L. J.; Li, J. D.; Jiang, Y. B.; Chem. Commun. 2012, 48, 2243.

15. Lin, C. Y.; Yu, C. J.; Lin, Y. H.; Tseng, W. L.; Anal. Chem. 2010, 82,6830 .

16. Qing, Z.; He, X.; Wang, K.; Zou, Z.; Yang, X.; Huang, J.; Yan, G.; Anal. Methods 2012, 4, 3320.

17. Xiao, Y.; Wu, Z.; Wong, K. Y.; Liu, Z.; Chem. Commun. 2014, $50,4849$.

18. Park, S. S.; Lee, J. Y.; Park, H. G.; Chem. Commun. 2012, 48, 4549.

19. Zheng, Y.; Yang, C.; Yang, F.; Yang, X.; Anal. Chem. 2014, 86, 3849.

20. Yang, Q.; Li, F.; Huang, Y.; Xu, H.; Tang, L.; Wang, L.; Fan, C.; Analyst 2013, 138, 2057.

21. Wen, Y. Q.; Xing, F. F.; He, S. J.; Song, S. P.; Wang, L. H.; Long, Y. T.; Li, D. C.; Fan, H.; Chem. Commun. 2010, 46, 2596.

22. Lotfi, B.; Tarlani, A.; Moghaddam, P. A.; Aghayan, M. M.; Peyghan, A. A.; Muzart, J.; Zadmar, R.; Biosens. Bioelectron. 2017, 90, 290.

23. Lin, Y. H.; Tseng, W. L.; Chem. Commun. 2009, 43, 6619.

24. Liu, G. P.; Yuan, Y. L.; Wei, S. Q.; Zhang, D. J.; Electroanalysis 2014, 26, 2732.

25. Zhang, Y. L.; Li, H. Y.; Xie, J. L.; Chen, M.; Zhang, D. D.; Pang, P. F.; Wang, H. B.; J. Electroanal. Chem. 2017, 785, 117.

26. Kim, J. H.; Kim, K. B.; Park, J. S.; Min, N.; Sens. Actuators, B 2017, 245, 741.

27. Yu, B.; Huang, Y. Y.; Zhou, J.; Guo, T.; Guan, B. O.; Talanta 2017, 165, 245.

28. Cui, H.; Paolucci, F.; Sojic, N.; Xu, G. B.; Anal. Bioanal. Chem. 2016, 408, 7001.

29. Pur, M. R. K.; Hosseini, M.; Faridbod, F.; Ganjali, M. R.; Hosseinkhani, S.; Sens. Actuators, B 2018, 257, 87.

30. Salehnia, F.; Hosseini, M.; Ganjali, M. R.; Anal. Methods 2018 , 10, 508.

31. Pur, M. R. K.; Hosseini, M.; Faridbod, F.; Ganjali, M. R.; Microchim. Acta 2017, 184, 3529.

32. LaBean, T. H.; Yan, H.; Kopatsch, J.; Liu, F.; Winfree, E.; Reif, J. H.; Seeman, N. C.; J. Am. Chem. Soc. 2000, 122, 1848.

33. Cui, L.; Wu, J.; Li, M. Q.; Ju, H. X.; Electrochem. Commun. 2015, 59, 77.

34. Murakami, T.; Sumaoka, J.; Komiyama, M.; Nucleic Acids Res. 2012, 40, e22. 
35. Zhang, D.; Zhang, Y.; Zheng, L.; Zhan, Y.; He, L.; Biosens. Bioelectron. 2013, 42, 112.

36. Yang, Y. Q.; Zhang, S.; Kang, M. M.; He, L. H.; Zhao, J. H.; Zhang, H. Z.; Anal. Biochem. 2015, 490, 7.

37. Zhang, Z. P.; Yan, J.; Sens. Actuators, B 2014, 202, 1058.

38. Yan, G. P.; Wang, Y. H.; He, X. X.; Wang, K. M.; Su, J.; Chen, Z. F.; Qing, Z. H.; Talanta 2012, 94, 178.

39. Xu, G.; Wang, G. F.; He, X. P.; Zhu, Y. H.; Chen, L.; Zhang, X. J.; Analyst 2013, 138, 6900.
40. Chang, C. C.; Lin, S. H.; Wei, S. C.; Yu, C. S.; Lin, C. W.; Anal. Bioanal. Chem. 2012, 402, 2827.

41. Sun, B.; Qi, H. L.; Ma, F.; Gao, Q.; Zhang, C. X.; Miao, W. J.; Anal. Chem. 2010, 82, 5046.

Submitted: October 8, 2018 Published onlline: February 5, 2019 